MAKALAH

\title{
DINAMIKA DAN PERKEMBANGAN PEMIKIRAN EROPA MODERN
}

Diajukan untuk memenuhi tugas Mata Kuliah Sejarah Eropa

(AKBK1206)

Dosen Pengampu

Dr. Mohamad Zaenal Arifin Anis, M.Hum.

Mansyur, S.Pd., M.Hum.

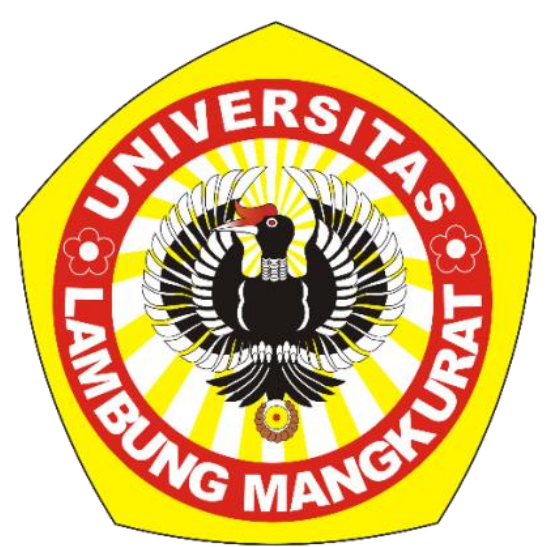

Disusun Oleh :

M. TAUFIK RIDHANI

2010111210017

MOHAMMAD RIZKY REZALDI

2010111210008

RISKI RAMADANI

2010111210024

Kelas A2

PROGRAM STUDI PENDIDIKAN SEJARAH JURUSAN PENDIDIKAN ILMU PENGETAHUAN SOSIAL

FAKULTAS KEGURUAN DAN ILMU PENDIDIKAN

UNIVERSITAS LAMBUNG MANGKURAT

BANJARMASIN

2021 


\section{KATA PENGANTAR}

Dengan memanjatkan puji syukur kehadirat Tuhan Yang Maha Esa atas karunia dan rahmat-Nya, kami dapat menyusun makalah yang berjudul "Dinamika Perkembangan dan Pemikiran Eropa Modern" dengan lancar.

Adapun maksud penyusunan makalah ini diajukan untuk memenuhi tugas mata kuliah Sejarah Eropa. Rasa terima kasih yang tidak terkirakan kepada yang terhormat dosen pengampu Bapak Dr. Mohamad Zaenal Arifin Anis, M.Hum. dan Bapak Mansyur, S.Pd., M.Hum. selaku pembimbing materi dalam pembuatan makalah ini, serta semua pihak yang telah mendukung dalam penyusunan makalah ini yang tidak bisa kami sebutkan satu persatu.

Banyak hal yang ingin kami sampaikan melalui makalah ini kepada pembaca mengenai perkembangan pemikiran Eropa. Harapannya, dengan adanya makalah ini dapat memperluas wawasan dan memperkaya pemikiran tentang perkembangan Sejarah Eropa

Kami menyadari makalah ini masih jauh dari kata sempurna dengan keterbatasan yang kami miliki. Tegur sapa dari pembaca akan kami terima dengan tangan terbuka demi perbaikan dan penyempurnaan makalah ini.

Banjarmasin, 14 Mei 2021

\section{Penulis}




\section{DAFTAR ISI}

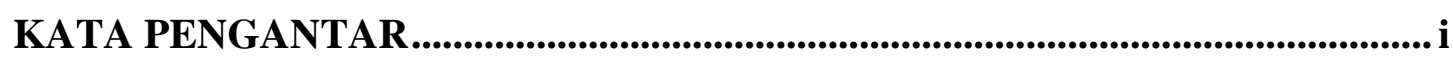

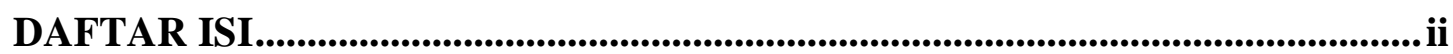

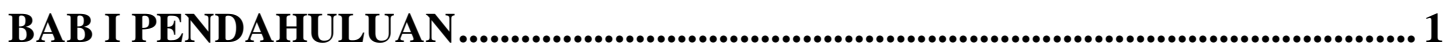

1.1 Latar Belakang Masalah......................................................................................... 1

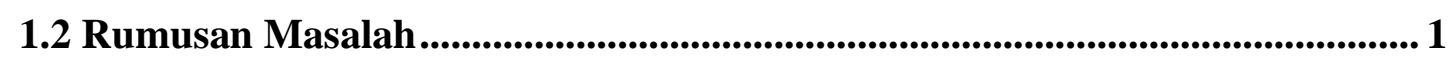

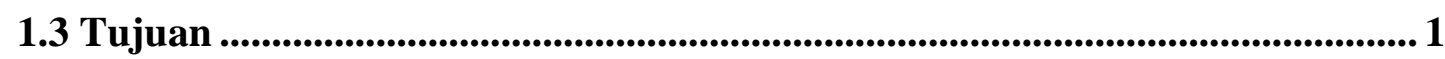

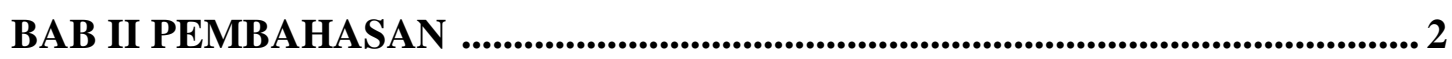

2.1 Revolusi Industri Inggris (1700-1900) ...............................................................2

2.2 Revolusi Perancis (1789-1799) ....................................................................................... 2

2.3 Revolusi Rusia (1917-1918) ...............................................................................3

2.4 Ideologi-Ideologi Besar Dunia....................................................................... 4

2.4.1 Ideologi Liberalisme ............................................................................................... 4

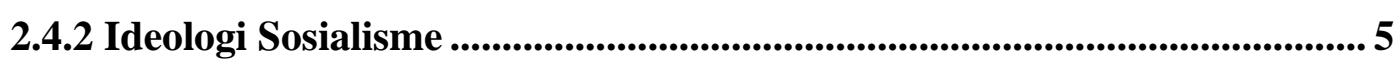

2.4.3 Ideologi Komunisme ................................................................................. 6

2.4.4 Ideologi Fasisme ..................................................................................................... 7

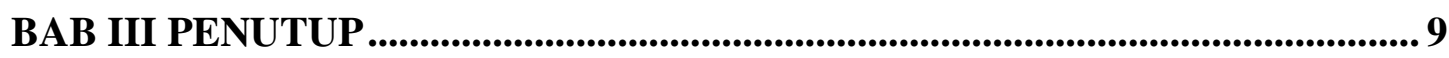

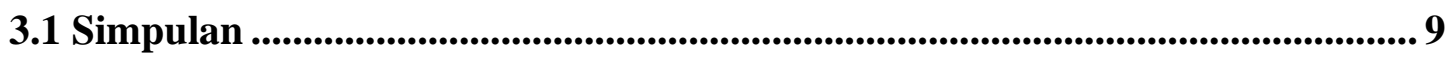

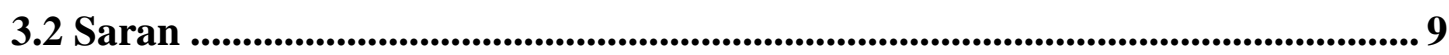

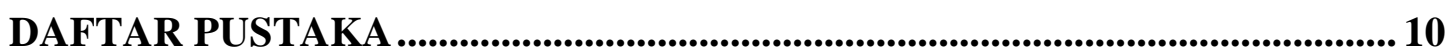




\section{BAB I \\ PENDAHULUAN}

\subsection{Latar Belakang Masalah}

Di era sekarang, sangat penting bagi kita untuk mengetahui dan mempelajari tentang sejarah. Melalui sejarah, diharapkan kita bisa mengingat bagaimana proses terjadinya peristiwa pada masa lampau dan dampaknya pada masa yang akan datang. Sejarah memiliki banyak manfaat, salah satunya dengan adanya sejarah kita dapat membuat sebuah perubahan yang lebih baik, lebih maju, dan lebih berkembang. Untuk mengenal sejarah diperlukan pemahaman terhadap ruang lingkup sejarah. Dalam rangkaian peristiwa pada masa lalu merupakan bagian dari ruang lingkup sejarah. Bukan hanya sekedar sebuah peristiwa lampau, namun dibalik arti sejarah tersebut mempunyai makna tersirat. Berbagai macam arti yang mempunyai pengaruh besar bagi kehidupan. Begitu banyak definisi sejarah, secara substansi sejarah merupakan sebuah ilmu tentang aktivitas manusia dalam rentang waktu. Dalam konteks ini diartikan, bahwa sejarah umat manusia selalu mengalami dinamika dan perubahan yang terus menerus (Anis, M. Z. A. 2015: 54).

Perkembangan sejarah eropa terutama pada jaman Eropa Modern banyak melahirkan tokoh-tokoh pemikir yang berkompeten dalam bidangnya. Ragam pemikiran dan pandangan mereka dalam mencetuskan teori memiliki perbedaantersendiri, hal ini dikarenakan latar belakang pendidikan dan bidang keahliannya yang berbeda. Namun, berkat perbedaan tersebut dapat memperkaya pemikiran dan wawasan kita tentang konsep negara yang mulai berkembang pada saat itu. Selain melahirkan tokoh pemikir, dinamika Eropa Modern juga ditandai dengan adanya peristiwa-peristiwa penting menjadi tonggal awal perubahan menuju modernitas dalam teknologi manufaktur.

Berdasarkan latar belakang diatas, maka pembahasan akan berfokus pada poin penting dalam perkembangan pemikiran Eropa Modern.

\subsection{Rumusan Masalah}

Adapun rumusan masalah dari penelitian ini adalah sebagai berikut :

1. Bagaimana dinamika sejarah perkembangan pemikiran Eropa Modern?

\subsection{Tujuan}

Adapun tujuan dari penelitian ini adalah sebagai berikut :

1. Untuk mengetahui dinamika sejarah perkembangan pemikiran Eropa Modern. 


\section{BAB II}

\section{PEMBAHASAN}

\subsection{Revolusi Industri Inggris (1700-1900)}

Revolusi Industri merupakan periode antara tahun 1750-1850 dimana terjadinya perubahan secara besar-besaran di bidang pertanian, manufaktur, pertambangan, transportasi, dan teknologi serta memiliki dampak yang mendalam terhadap kondisi sosial,ekonomi, dan budaya di dunia. Revolusi Industri dimulai dari Britania Raya dan kemudian menyebar ke seluruh Eropa Barat, Amerika Utara, Jepang, dan akhirnya ke seluruh dunia. Revolusi Industri menandai terjadinya titik balik besar dalam sejarah dunia, hampir setiap aspek kehidupan sehari-hari dipengaruhi oleh Revolusi Industri, khususnya dalam hal peningkatan pertumbuhan penduduk dan pendapatan rata-rata yang berkelanjutan dan belum pernah terjadi sebelumnya. Selama dua abad setelah Revolusi Industri, rata-rata pendapatan perkapita negara-negara di dunia meningkat lebih dari enam kali lipat. Seperti yang dinyatakan oleh pemenang Hadiah Nobel, Robert Emerson Lucas, bahwa: "Untuk pertama kalinya dalam sejarah, standar hidup rakyat biasa mengalami pertumbuhan yang berkelanjutan. Perilaku ekonomi yang seperti ini tidak pernah terjadi sebelumnya".

Sebelum Abad ke-18 suatu sistem perekonomian masyarakat Eropa ini bergantung pada sistem ekonomi agraris. Akan tetapi, setelah memasuki abad ke-18 maka terjadilah dan mulai digunakan tenaga mesin sebagai alat produksi di pabrikpabrik menggantikan tenaga manusia. Perubahan inilah yang disebut menjadi mesin uap yang dikenal dengan Revolusi Industri. Revolusi Industri Inggris dipelopori oleh Fredriech Engles dan Louis Agueste Blanqui di pertengahan abad ke - 19. Sebelum dikenal dengan alat-alat mekanis dan otomatis, masyarakat Eropa bekerja dengan menggunakan alat-alat manual. Pada masa Revolusi Industri dan peralatan tersebut jarang digunakan sebab telah dicantumkan mesin pemintal, mesin tenun, lokomotif dan sebagainya. Semua mesin tersebut akan digunakan dalam sebuah mesin Uap oleh tangan dan kaki manusia. Revolusi Industri terjadi suatu penghematan dan perbedaan pola hidup masyarakat sangat terlihat.

Revolusi Industri ini membawa dampak yang lebih besar dan positif dalam suatu kehidupan masyarakat baik itu dalam sosial dan budaya, ekonomi, Teknologi. Tidak hanya membawa dampak yang negatif saja tetapi juga positifnya. Revolusi Industri memang menggantikan tenaga Manusia dengan Mesin sehingga kesejahteraan masyarakat hal ini juga berdampak pada faktor sosial dan budaya dan ekonomi, akibatnya politik kurang stabil (Fajariah, M., \& Suryo, D. 2020: 74).

\subsection{Revolusi Perancis (1789-1799)}

Revolusi Perancis merupakan pemberontakan berbagai kelas dalam masyarakat 
terhadap seluruh tatanan kehidupan berbangsa dan bernegara. Revolusi ini dipicu oleh kesusahan yang berkepanjangan. Perancis menjadi sangat miskin akibat tiga perang besar sejak 1740. Kegagalan panen mengakibatkan harga bahan pangan meningkat drastis. Kekuasaan hanya berpusat pada istana Versailles dan segala bentuk kritik pada pemerintahan dianggap sebagai tindakan yang ilegal. Kaum bangsawan berkuasa layaknya tuan tanah feodal yang memberikan utang berbunga tinggi. Dengan inspirasi pemikiran Abad Pencerahan, kaum berpendidikan kelas menengah mulai berpikir untuk mengubah "status quo". Jadi, Revolusi Perancis merupakan sebuah revolusi yang terjadi pada tahun 1789 yang bergerak untuk menentang berbagai masalah yang dirasakan tidak benar karena adanya sistem absolutisme dalam pemerintahan yang diterapkan oleh penguasa atau rajanya. Inilah salah satu akibat dari meletusnya Revolusi Perancis. Situasi di Negara Perancis pada akhir abad 18, diliputi suasana yang serba tidak adil, rakyat hidup dalam suasana ketakutan dan menderita. Oleh karena itu, Revolusi Perancis meletus untuk menentang absolutisme untuk menciptakan prinsipprinsip demokrasi dalam menyusun masyarakat baru yang berdasarkan kemerdekaan atau kebebasan, persamaan hak, dan persaudaraan. Revolusi Perancis sebagai obyek studi sejarah rupanya terus-menerus menarik perhatian serta menghasilkan penulisan sejarah yang tak habis-habisnya, tidak lain karena peristiwa itu sebagai fenomena sejarah tidak hanya mempunyai sifat amat kompleks dan dampak luas tetapi juga memiliki relevansi besar terhadap berbagai permasalahan masa kini, khususnya bagi negeri-negeri berkembang yang sedang menyelenggarakan pembangunan (Rahmawati, E. 2013).

\subsection{Revolusi Rusia (1917-1918)}

Pada permulaan abad-19 keadaan Rusia masih sangat terbelakang jika dibandingkan dengan keadaan Eropa Barat. Masyarakat Rusia terbagi atas dua golongan, yaitu tuan tanah (bangsawan dan petani (rakyat jelata). Industri belum ada dan karena itu belum ada kaum pertengahan (borjuis). Rusia masih merupakan negara agraris yang kolot. Tidak adanya kaum borjuis mempersulit masuknya liberalisme ke Rusia, karena lazimnya kaum borjuis merupakan kaum pendukung liberalisme.

Sebagaimana revolusi yang terjadi di Perancis sekitar tahun 1789-1795 yang timbul karena ketidakpuasan masyarakat terhadap pemerintah, keinginan untuk menghapus feodalisme, dan adanya diskriminasi terhadap golongan. Sehingga membuat golongan tersebut iri dengan melakukan sebuah pergerakan perubahan yang disebut sebagai revolusi Perancis. Revolusi yang terjadi di Rusia terilhami dari Revolusi Perancis yang menuntut persamaan hak dan kewajiban serta Undang-undang yang sama bagi semua kelas. Revolusi seperti ini juga terjadi di Rusia yang dikarenakan ketidakpuasan kaum buruh yang selalu diperas tenaganya tetapi mendapatkan gaji yang rendah. Para pengusaha dapat mendapatkan kekayaan dan harta benda yang banyak, 
tetapi berbeda dengan kaum buruh yang tidak mendapatkan apa-apa. (Brinton, Crane. 1962 dalam Afandi, A., Harthanti, D., \& Nurhayati, N. 2018).

H.G Wells 2013 (dalam Afandi, A., Harthanti, D., \& Nurhayati, N. 2018) Revolusi Rusia terjadi pada masa pemerintahan Tsar Nicholas II. Nicholas II bersifat Reaksioner dan meneruskan politik Alexander III, ialah reaksioner dalam urusan pemerintahan tetapi progresif dalam urusan ekonomi. Industrialisasi diperhebat. Tetapi dengan majunya Industrialisasi, gerakan-gerakan sosialisme juga semakin maju. Akhirnya ia juga menjadi korban gerakan Sosialisme.

Pada tahun 1917 ia turun tahta, ditangkap dan dibuang ke Siberia. Pada tahun 1918 ia dengan keluarganya dibunuh oleh kaum Bolshevik. Kaum buruh di Rusia dari tahun ke tahun semakin meningkat dikarenakan semakin banyaknya perusahaanperusahaan Industri yang ada pada saat itu yang membutuhkan tenaga kerja yang banyak pula. Hanya kaum buruh, kaum borjuis, dan kaum petani juga tidak setuju dengan apa yang dilakukan pemerintah dimana bangsawan-bangsawan pemilik perusahaan semakin kaya sedangkan tingkatan dibawahnya tidak bertambah kekayaannya bahkan berkurang kekayaannya dikarenakan dominasi bangsawan. Sehingga perusahaan revolusioner pun muncul dan telah berkali-kali dinyatakan baik dari golongan borjuis, buruh dan petani yang terilhami dari Revolusi Perancis dan evolusi yang terjadi di Eropa.

\subsection{Ideologi-Ideologi Besar Dunia}

\subsubsection{Ideologi Liberalisme}

Sejarah liberalisme dimulai dari zaman Renaissance, sebagai reaksi terhadap ortodoksi religius. Saat itu kekuasaan gereja mendominasi seluruh aspek kehidupan manusia. Semua aturan kehidupan ditentukan dan berada di bawah otonomi gereja. Hasilnya, manusia tidak memiliki kebebasan dalam bertindak, otonomi individu dibatasi dan bahkan ditiadakan. Kondisi ini memicu kritik dari berbagai kalangan, yang menginginkan otonomi individu dalam setiap tindakan dan pilihan hidup. Otonomi individu dipahami sebagai keterbebasan dari determinasi dan intervensi eksternal, berupa pembatasan, pemaksaan atau berbagai bentuk ancaman dan manipulasi, dalam melakukan tindakan. Menurut liberalisme, individu adalah pencipta dan penentu tindakannya. Dengan konsep seperti ini, maka kesuksesan dan kegagalan seseorang ditentukan oleh dirinya sendiri, oleh tindakan-tindakannya dan pilihan-pilihan terhadap tindakan tersebut. Intinya, manusia memiliki kebebasan dalam hidupnya, manusia adalah pribadi yang otonom.

Dalam perkembangannya, ada dua corak liberalisme, liberalisme yang dipelopori oleh John Locke dan liberalisme yang dipelopori oleh Jean Jacques Rousseau. John Locke berpendapat bahwa kebebasan yang menjadi nilai dasar liberalisme dipahami sebagai ketidakhadiran intervensi eksternal dalam 
aktivitas-aktivitas individu. Kebebasan adalah hak properti privat. Karenanya, pemerintah bersifat terbatas (minimal) terhadap kehidupan warganya. Untuk itu harus ada aturan hukum yang jelas dan lengkap dalam menjamin kebebasan sebagai hak properti privat ini. Corak liberalisme ini kemudian mendasari dan menginspirasi munculnya libertarianisme yang dipelopori oleh Alexis de Tocqueville, Friedrich von Hayek dan Robert Nozick.

Di sisi lain Rousseau berpendapat bahwa pemerintah harus tetap berfungsi menjamin terlaksananya kebebasan individu dalam masyarakat. Corak liberalisme ini selanjutnya mendasari dan menginspirasi munculnya liberalisme egalitarian, dengan tokohnya antara lain John Rawls dan Ronald Dworkin. Liberalisme ini berusaha menyatukan ide kebebasan dan kesamaan individu dalam masyarakat. Pemerintah dibutuhkan untuk meredistribusikan nilai-nilai sosial dalam melaksanakan dan mencapai kebebasan dan kesamaan individu-individu dalam masyarakat. Perbedaan terpenting antara liberalisme dan libertarianisme adalah pandangan tentang kebebasan individu. Menurut libertarianisme, kebebasan yang menjadi hak individu merupakan satu bentuk properti privat, tidak seorang pun atau apa pun yang dapat merampas dan mencabutnya dari seseorang tanpa dianggap telah melanggar hak orang tersebut. Seperti libertarianisme, liberalisme juga mengutamakan kebebasan. Kebebasan menurut liberalisme tidak dapat dikorbankan untuk nilai yang lain, untuk nilai ekonomi, sosial dan politik. Kebebasan hanya dapat dibatasi dan dikompromikan ketika ia konflik dengan kebebasan dasar yang lain yang lebih luas. Karenanya, kebebasan menurut liberalisme bukan sesuatu yang absolut, kebebasan hanya dapat dibatasi demi kebebasan itu sendiri (R. Aida. 2005: 96).

\subsubsection{Ideologi Sosialisme}

Sosialisme adalah pandangan hidup dan ajaran kamasyarakatan tertentu yang berhasrat untuk menguasai sarana-sarana produksi serta pembagian hasilhasil produksi secara merata. Sosialisme sebagai ideologi politik adalah dianggap sebagai suatu keyakinan dan kepercayaan yang benar oleh para pengikutnya mengenai tatanan politik yang mencita-citakan terwujudnya kesejahteraan masyarakat secara merata melalui jalan evolusi, persuasi, konstitusional-parlementer, dan tanpa kekerasan.

Sosialisme sebagai ideologi politik timbul dari keadaan yang kritis di bidang sosial, ekonomi dan politik akibat revolusi industri. Adanya kemiskinan, kemelaratan, kebodohan kaum buruh, maka sosialisme berjuang untuk mewujudkan kesejahteraan secara merata. Dalam perkembangan sosialisme terdiri dari berbagai macam bentuk seperti sosialisme utopia, sosialisme ilmiah yang kemudian akan melahirkan berbagai aliran sesuai dengan nama pendirinya 
atau kelompok masyarakat pengikutnya seperti Marxisme-Leninisme, Febianisme dan Sosial Demokratis.

Sosialisme dapat tumbuh dan berkembang dengan baik pada masyarakat bangsa yang memiliki tradisi demokrasi yang kuat. Unsur-unsur pemikiran yang ada dalam gerakan sosialis sebagimana tergambar di Inggris mencakup : (a) agama; (b) idealisme etis dan estetis; (c) empiris Fabian; dan (d) liberalisme. Sosialisme yang ada disetiap negara memiliki ciri khas sesuai dengan kondisi sejarahnya. Sumber sejarah berasal dari jejak atau kesaksian yang ditinggalkan dalam peristiwa, kemudian ditafsirkan oleh sejarawan sehingga dapat menceritakan realitas masa lalu (Anis, M. Z. A. 2015: 54). Dalam sosialisme tidak ada garis sentralitas dan tidak bersifat internasional.

Sosialisme di negara-negara berkembang mengandung banyak arti. Sosialisme berarti cita-cita keadilan sosial; persaudaraan; kemanusiaan dan perdamaian dunia yang berlandaskan hukum; dan komitmen pada perencanaan. Sedangkan, di negara-negara Barat (lebih makmur) sosialisme diartikan sebagai cara mendistribusikan kekayaan masyarakat secara lebih merata sedangkan di Negara berkembang sosialisme diartikan sebagai cara mengindustrialisasikan Negara yang belum maju atau membangun suatu perekonomian industri dengan maksud menaikkan tingkat ekonomi dan pendidikan masyarakat. Sosialisme sebagai ideologi politik yang merupakan keyakinan dan kepercayaan yang dianggap benar mengenai tatanan politik yang mencita-citakan terwujudnya kesejahteraan masyarakat secara merata melalui jalan evolusi, persuasi, konstitusional-parlementer dan tanpa kekerasan (Puspitasari, R. Tanpa Tahun).

\subsubsection{Ideologi Komunisme}

Kata Komunisme muncul di Perancis sekira tahun 1830 berbarengan dengan munculnya kata sosialisme. Dua kata ini semula sama artinya tetapi kata Komunisme dipakai untuk aliran sosialis yang lebih radikal, yang menuntut penghapusan total hak milik pribadi dan kesamaan konsumsi serta mengharapkan keadaan lebih baik bukan dari kebaikan pemerintah tetapi dari perjuangan kaum miskin/terhisap. Hunt menuliskan socialism and communism are virtually interchangeable terms. The essence of both is that the means of production shall belong to the community. Kamus Besar Bahasa Indonesia menuliskan Komunis adalah penganut paham komunisme.

Paham Komunis tidak terlepas dari gagasan bahwa kekayaan dunia merupakan milik bersama dan lebih baik dari milik pribadi. Kepemilikan bersama menjadi gagasan yang mendorong membuat sama rata dalam situasi ekonomi semua orang, meniadakan perbedaan antara si miskin dan si kaya, menggantikan usaha mengejar keuntungan pribadi dengan kesejahteraan 
umum, sehingga dimungkinkan tidak terjadi situasi sosial yang dapat menjadi pembeda di antara semua orang. Gagasan ini lebih lanjut disebut dengan paham sosialisme. Oleh karena itu paham komunis tidak terlepas dan teridentikan dari gagasan/paham sosialis.

Ajaran Karl Marx (Marxisme) tidaklah identik bahkan sama dengan komunisme yang ada dalam dasawarsa sekarang ini di Rusia, Indonesia, Cina dan Kuba misalnya karena, komunisme yang ada merupakan gerakan dan kekuatan politik yang terorganisir sebagai organisasi kepartaian (Partai Komunis) untuk mendapatkan kekuasaan. Partai Komunis ada pada Oktober 1917 di bawah pimpinan W.I. Lenin sebagai kekuatan politik dan ideologi internasional. Namun demikian komunis sebagai kekuatan politik pastilah membutuhkan ideologi sebagai perekat kekuatan, oleh karena itu ajaran Karl Marx dijadikan sebagai ideologi Partai Komunis/ajaran komunisme (Marxisme-Leninisme). Dengan demikian Marxisme dijadikan sebagai komponen idiologi Partai Komunisme bukan komunisme sebagai kekuatan politik itu sendiri (Rujikartawi, E. 2016: 76-78).

\subsubsection{Ideologi Fasisme}

Fasisme berasal dari kata fascio dari kata fasces yang berarti seikat tongkat dan kapak. Menurut para ahli sejarah bangsa Italia, fasisme adalah fascio di combattimento, yang artinya kurang lebih-persatuan perjuangan. Fasisme adalah pengaturan pemerintahan dan masyarakat secara totaliter oleh suatu kediktatoran partai tunggal yang sangat nasionalis, rasialis, militeris, dan agresif imperialis. Paham fasisme hampir bersamaan dianut oleh tiga negara, yaitu Italia, Jerman dan Jepang.

Fasisme merupakan sebuah paham politik kekuasaan absolut tanpa demokrasi, paham yang mengedepankan bangsa sendiri dan memandang rendah bangsa lain. Dengan kata lain, fasisme adalah suatu sikap nasionalisme yang berlebihan. Fasisme adalah gerakan radikal ideologi nasionalis otoriter politik. Fasis berusaha untuk mengatur bangsa menurut perspektif korporatis, nilai, dan sistem, termasuk sistem politik dan ekonomi. Mereka menganjurkan pembentukan partai tunggal negara totaliter yang berusaha mobilisasi massa suatu bangsa dan terciptanya negara yang ideal untuk membentuk suatu elit pemerintahan melalui indoktrinasi, pendidikan fisik, dan eugenika kebijakan keluarga. Fasis percaya bahwa bangsa memerlukan kepemimpinan yang kuat, identitas kolektif tunggal, dan akan dan kemampuan untuk melakukan kekerasan dan berperang untuk menjaga bangsa yang kuat.

Fasisme adalah anti-komunisme, anti-demokratis, anti-individualis, antiliberal, anti-parlemen, anti-konservatif, anti-borjuis dan anti-proletar, dan dalam banyak kasus anti-kapitalis Fasisme. menolak konsep-konsep 
egalitarianisme, materialisme, dan rasionalisme yang mendukung tindakan, disiplin, hierarki, dan semangat. Dalam ilmu ekonomi, fasis menentang liberalisme sebagai gerakan borjuis dan Marxisme sebagai sebuah gerakan proletar untuk menjadi eksklusif ekonomi berbasis kelas gerakan Fasis.

Ideologi mereka seperti yang dilakukan oleh gerakan ekonomi transkelas yang mempromosikan untuk menyelesaikan konflik kelas ekonomi dan mengamankan solidaritas nasional dengan cara mereka mendukung, diatur multi-kelas, sistem ekonomi nasional yang terintegrasi. Pemerintah Fasis melarang dan menekan oposisi terhadap negara. Fasisme didirikan oleh sindikalis nasional Italia dalam Perang Dunia I yang menggabungkan sayap kiri dan sayap kanan pandangan politik, tapi condong ke kanan di awal 1920-an. Para sarjana umumnya menganggap fasisme berada di paling kanan. Fasis meninggikan kekerasan, perang, dan militerisme sebagai memberikan perubahan positif dalam masyarakat, dalam memberikan renovasi spiritual, pendidikan, menanamkan sebuah keinginan untuk mendominasi dalam karakter orang dan menciptakan persaudaraan nasional melalui dinas militer. Fasis melihat kekerasan dan perang sebagai tindakan yang menciptakan regenerasi semangat, nasional dan vitalitas.

Paham Fasisme di Jerman disebut Nazisme. Nazi adalah suatu partai di bawah pimpinan Adolf Hitler. Seusai Perang Dunia I, Jerman berubah menjadi Republik yang semula adalah kerajaan. Pemimpin pertama adalah Ebert, Berkuasa antara tahun 1919-1925, pemimpin selanjutnya adalah Presiden Hindenburg (1925-1934). Dalam pemerintahan republik ini, Jerman mengalami berbagai macam kesulitan, Baik dalam keuangan (Inflasi) maupun kekacauan ekonomi. Dalam keadaan Negara yang kacau tersebut rakyat Jerman mengharapkan orang yang kuat untuk memperbaiki keadaan. Dalam suasana yang kacau ini muncullah Adolf Hitler dengan partai ekstrem yaitu NAZI. 


\section{BAB III \\ PENUTUP}

\subsection{Simpulan}

Adapun dinamika sejarah perkembangan pemikiran pada masa Eropa Modern ditandai dengan adanya revolusi-revolusi dunia dan ideologi-ideologi besar dunia. Revolusi Industri Inggris dipelopori oleh Fredriech Engles dan Louis Agueste Blanqui di pertengahan abad ke-19. Sebelum dikenal dengan alat-alat mekanis dan otomatis, masyarakat Eropa bekerja dengan menggunakan alat-alat manual. Revolusi Perancis merupakan pemberontakan berbagai kelas dalam masyarakat terhadap seluruh tatanan kehidupan berbangsa dan bernegara. Revolusi ini dipicu oleh kesusahan yang berkepanjangan. Perancis menjadi sangat miskin akibat tiga perang besar sejak 1740. Revolusi Rusia terjadi pada masa pemerintahan Tsar Nicholas II. Nicholas II bersifat Reaksioner dan meneruskan politik Alexander III, ialah reaksioner dalam urusan pemerintahan tetapi progresif dalam urusan ekonomi. Industrialisasi diperhebat. Tetapi dengan majunya Industrialisasi, gerakan-gerakan sosialisme juga semakin maju. Akhirnya ia juga menjadi korban gerakan Sosialisme. Selain itu, ideologi besar dunia yang berkembang pada saat itu terdapat ideologi liberalisme, ideologi sosialisme, ideologi komunisme dan ideologi fasisme. Sosialisme sebagai ideologi politik timbul dari keadaan yang kritis di bidang sosial, ekonomi dan politik akibat revolusi industri. Adanya kemiskinan, kemelaratan, kebodohan kaum buruh, maka sosialisme berjuang untuk mewujudkan kesejahteraan secara merata. Paham Komunis tidak terlepas dari gagasan bahwa kekayaan dunia merupakan milik bersama dan lebih baik dari milik pribadi. Kepemilikan bersama menjadi gagasan yang mendorong membuat sama rata dalam situasi ekonomi semua orang, meniadakan perbedaan antara si miskin dan si kaya, menggantikan usaha mengejar keuntungan pribadi dengan kesejahteraan umum, sehingga dimungkinkan tidak terjadi situasi sosial yang dapat menjadi pembeda di antara semua orang. Gagasan ini lebih lanjut disebut dengan paham sosialisme. Fasisme merupakan sebuah paham politik kekuasaan absolut tanpa demokrasi, paham yang mengedepankan bangsa sendiri dan memandang rendah bangsa lain. Dengan kata lain, fasisme adalah suatu sikap nasionalisme yang berlebihan. Paham Fasisme di Jerman disebut Nazisme. Nazi adalah suatu partai di bawah pimpinan Adolf Hitler.

\subsection{Saran}

Adapun saran yang dapat kami berikan kepada pembaca makalah ini agar dapat menjadikan dinamika sejarah perkembangan Eropa Modern sebagai penambah wawasan tentang revolusi dan ideologi yang mana dalam perkembangannya sangat berpengaruh dalam kehidupan masyarakat Eropa saat itu. 


\section{DAFTAR PUSTAKA}

Anis, M. Z. A. (2015). Sejarah Bukan Warisan Melainkan Pembelajaran.

Anis, M. Z. A. (2016). Sejarah, Kesadaran Sejarah dan Pupusnya Identitas Nasional.

Fajariah, M., \& Suryo, D. (2020). Sejarah Revolusi Industri di Inggris Pada Tahun 1760-1830. HISTORIA: Jurnal Program Studi Pendidikan Sejarah, 8(1), $77-$ 94.

Rahmawati, E. (2013). Peranan Kaum Borjuis Terhadap Munculnya Revolusi Prancis (Doctoral dissertation, FIS).

Afandi, A., Harthanti, D., \& Nurhayati, N. (2018). Revolusi Rusia (Bolshevik) Dan Pengaruh Terhadap Kehidupan Sosial, Ekonomi Dan Politik Rusia Pada Tahun 1917-1922. Historis: Jurnal Kajian, Penelitian dan Pengembangan Pendidikan Sejarah, 3(2), 42-50.

R. Aida. (2005). Liberalisme dan Komunitarianisme: Konsep tentang Individu dan Komunitas. Jurnal Demokrasi 4(2).

Puspitasari, R. (Tanpa Tahun). Revolusi Perancis, Revolusi Industri, Perkembangan Ideologi Kapitalisme, Sosialisme, Liberalisme Dan Demokrasi Dan Dampaknya Bagi Masyarakat Dunia, Perkembangan Masyarakat Jepang Sejak Restorasi Meiji Dan Dampaknya Di Dalam Dan Luar Negeri. Pertemuan7pmg.

Putra, A. R. (Tanpa Tahun). Ideologi Fasisme (Pemikiran Adolf Hitler Atas Konsep Fasisme di Jerman).

Rujikartawi, E. (2016). Komunis; Sejarah Gerakan Sosial Dan Ideologi Kekuasaan. Qathruna, 2(02), 75-86. 